\title{
Injection practices among practitioners in private medical clinics of Karachi, Pakistan
}

\author{
M.T. Yousafzai, ${ }^{1,2}$ N. Nisar, ${ }^{3,6}$ M.F. Kakakhel, ${ }^{4}$ M.H. Qadri, ${ }^{1,5}$ R. Khalil' and S.M. Hazara ${ }^{6,7}$
}

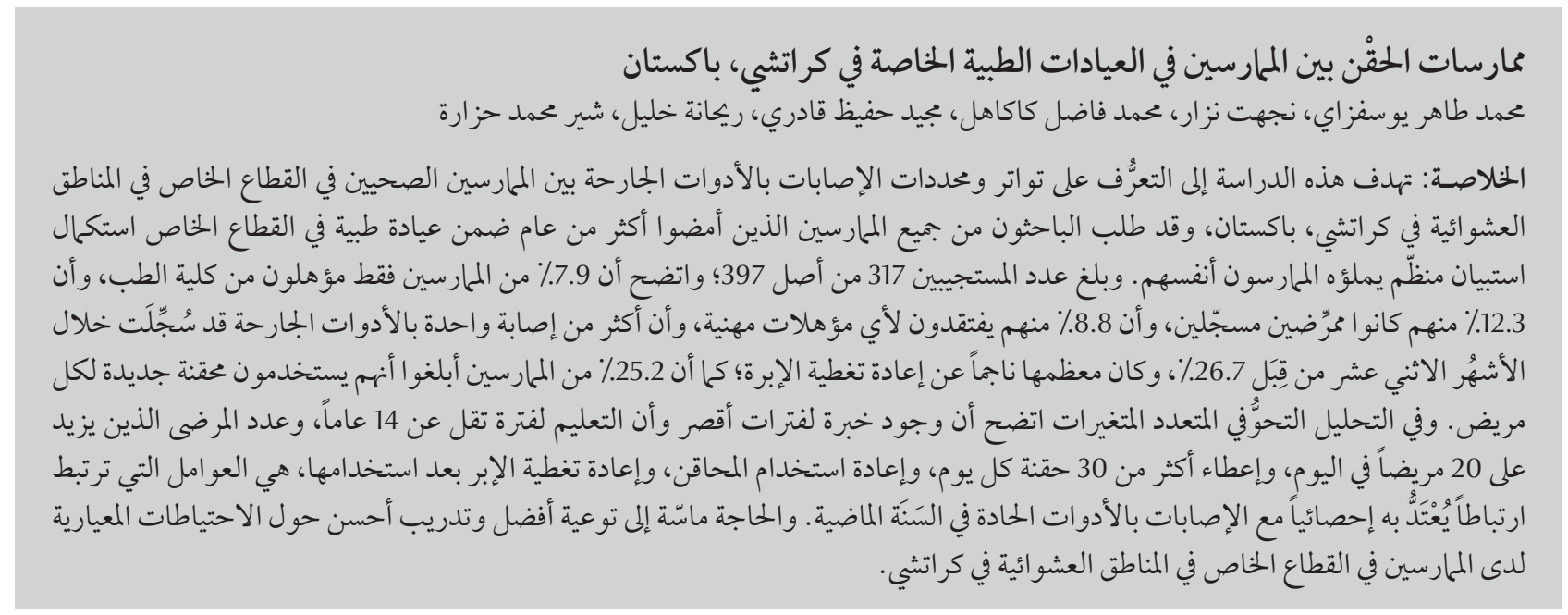

ABSTRACT The aim of this study was to determine the frequency and determinants of sharps injuries among private health practitioners in slum areas of Karachi, Pakistan. All practitioners with at least 1 year of experience in a private medical clinic were asked to complete a self-administered, structured questionnaire (317/397 responded). Only $7.9 \%$ of practitioners were qualified from medical school, $12.3 \%$ were registered nurses and $8.8 \%$ lacked any professional qualifications. At least 1 sharps injury in the previous 12 months was reported by $26.7 \%$, mostly due to needle recapping. Only $25.2 \%$ reported using a new syringe for each patient. In multivariate regression analysis shorter work experience, $<14$ years of schooling, $>20$ patients per day, administering $\geq 30$ injections per day, reuse of syringes and needle recapping after use were significantly associated with sharps injury in the past year. Better awareness and training on standard precautions is needed for private practitioners in slum areas of Karachi.

\section{Pratiques d'injection chez les praticiens des établissements médicaux privés à Karachi (Pakistan)}

RÉSUMÉ L'objectif de la présente étude était de déterminer la fréquence et les déterminants des blessures par objets piquants ou tranchants chez les praticiens de santé privés dans les bidonvilles de Karachi (Pakistan). Tous les praticiens ayant au moins un an d'expérience dans un établissement médical privé ont été sollicités pour remplir un auto-questionnaire structuré (317/397 ont répondu). Seuls 7,9\% des praticiens étaient diplômés d'une école de médecine ; 12,3 \% avaient le diplôme d'infirmier tandis que 8,8 \% ne possédaient aucune qualification professionnelle. Ils étaient 26,7 \% à déclarer avoir été blessés au moins une fois par un objet piquant ou tranchant au cours des 12 derniers mois, principalement à cause d'un recapuchonnage d'aiguille. Seuls 25,2 \% ont affirmé utiliser une nouvelle seringue pour chaque patient. À l'analyse de régression multivariée, une expérience plus courte, une scolarité inférieure à 14 années, le fait d'avoir plus de 20 patients par jour, l'administration d'au moins 30 injections par jour, la réutilisation des seringues et le recapuchonnage des aiguilles après utilisation étaient fortement associés aux blessures par objets piquants ou tranchants au cours de l'année écoulée. Il est nécessaire que les praticiens privés des bidonvilles de Karachi soient davantage sensibilisés et mieux formés aux précautions standard.

${ }^{7}$ Faculty of Health Sciences, Baqai Medical University, Karachi, Pakistan (Correspondence to M.T. Yousafzai: m.tahir.yousafzai@gmail.com). ${ }^{2} J i n n a h$ Medical and Dental College, Karachi, Pakistan. ${ }^{3}$ Department of Community Medicine, Dow Medical College, Karachi, Pakistan. ${ }^{4}$ Kyrgyz State Medical Academy, Bheshkek, Kyrgyzstan. ${ }^{5}$ Shaheed Benazir Bhutto Medical College, Karachi, Pakistan. ${ }^{6}$ Dow University of Health Sciences, Karachi, Pakistan. ${ }^{7}$ National Medical Centre, Karachi, Pakistan.

Received: 21/11/11; accepted: 06/05/12 


\section{Introduction}

According to World Health Organization estimates, $40 \%-65 \%$ of hepatitis $\mathrm{B}$ virus (HBV) and $\mathrm{C}$ virus ( $\mathrm{HCV}$ ) infections among health-care workers (HCW) in the developing world are due to occupational sharps injuries, in contrast to $8 \%-27 \%$ of HCV and < $10 \%$ of HBV infections in the developed regions [1]. In the developing world the risk of bloodborne infection among $\mathrm{HCW}$ is exacerbated by poor health care regulations about workplace safety conditions, the lack of safety engineered devices (e.g. auto-disable syringes, safer needle devices) and personal protective equipment (e.g. gloves, goggles, masks, gowns) and poor compliance with universal precautions (e.g. hand washing, not recapping needles, proper disposal of sharps in separate sharps container, wearing gloves, gowns, masks and eye goggles) especially in situations where there is possibility of blood or body fluid exposure [2,3]. Other factors contributing to the high number of needlestick injuries are the culture (patient demand) of using injections versus other methods, the large number of informal, unlicensed practitioners, the lack of vaccination coverage against HBV [4], the lack of availability of postexposure prophylaxis and a high prevalence of bloodborne infections among the general population $[2,5]$.

Data on injection practices among health care practitioners at private clinics in Pakistan are scarce. Clinics located in slum areas are different from hospitals in terms of resources and qualifications and essential training of the practitioners. A study was therefore conducted at private clinics in slum areas of Karachi where a multiethnic population resides. It was hoped that the study would provide important data for policy-makers and other concerned medical and nursing associations to take necessary actions to prevent occupational transmission of bloodborne infections. The aim of this study was to determine the frequency and determinants of sharps injuries among practitioners working in private health care clinics in slum areas of Karachi, Pakistan.

\section{Methods}

\section{Study design and setting}

A cross-sectional study was carried out during May to July 2006 in Landhi town, Karachi, in the Majeed, Bilal, Muslimabad, Muzafarabad and Sherpao colonies. The estimated population was more than 35000 , comprising a mix of Pashtu, Panjabi and Urdu speakers. A majority of the people work in the garment and textile industries. At the time of the study there was 1 social security hospital providing free-of-charge health care for factory workers only. In addition there were 2 public dispensaries providing vaccinations and treatment for minor illnesses. The majority of the population obtained treatment from private clinics which are available in every street, providing treatment for all types of minor illness around the clock. The majority of these private clinics are run by unqualified, unlicensed practitioners ("quacks"). The study was approved by the ethics committee of Baqai Medical University.

\section{Sampling and eligibility criteria}

An initial survey was done to formulate the list of private health care practitioners: clinic address, name of the practitioner, work experience of the practitioner in the clinic and working hours. There were a total of 407 private clinics located in the given area. Consent was sought from all the practitioners who had work experience of at least 1 year in the given clinic. Overall 317 out of 397 (79.8\%) practitioners consented to participate in the study.

\section{Data collection and tools}

A structured, pre-tested questionnaire in the English language was used for data collection. Questionnaires were distributed among all the eligible practitioners who consented to participate in the study. Practitioners were asked to complete the questionnaires within a 1-week period at any time when they were free. After 1 week, data collectors visited again to collect the filled questionnaires. Practitioners who were unable to complete it or were absent on the given day were revisited after 3 days to collect the filled questionnaires.

\section{Statistical analysis}

Data was analysed using SPSS, version 19. Frequencies with percentage for categorical and mean with standard deviation (SD) for continuous scale variables were calculated. Prevalence with $95 \%$ confidence interval (CI) of at least 1 sharps injury in the last 12 months was measured. Crude and adjusted odds ratios (OR) for predictors of sharps injury were calculated using multivariable logistic regression analysis. Confounding variables were identified through changes in crude and adjusted beta coefficients for the particular variable. A cut-off value of $\geq 10 \%$ in beta coefficient was considered as a confounder. Hosmer and Lemeshow goodness-of-fit test was used to evaluate the model adequacy. Insignificant $P$-value for Hosmer and Lemeshow indicated that the model was a good fit.

\section{Results}

\section{Participants' profile}

Data were collected from 317 practitioners; Table 1 showed their sociodemographic and other characteristics. There were 277 (87.4\%) males and 40 (12.6\%) females; $41.0 \%$ of the practitioners were of Panjabi, Sindhi or Hazarawal ethnicity, 34.7\% Pashtu and $24.3 \%$ were Urdu speaking. The mean age was 38 (SD 11) years, while mean work experience was 12 (SD 9) years. Almost two-thirds of the practitioners (63.1\%) had $\leq 12$ years' of schooling, 


\begin{tabular}{|c|c|c|}
\hline Variable & & \\
\hline \multicolumn{3}{|c|}{ Demographic variables } \\
\hline Age in years [mean $(S D)$ ] & & \\
\hline \multicolumn{3}{|l|}{ Sex [no., \%] } \\
\hline Male & 277 & 87.4 \\
\hline Female & 40 & 12.6 \\
\hline Years of work experience [mean (SD)] & & \\
\hline \multicolumn{3}{|l|}{ Ethnicity [no., \%] } \\
\hline Pashtu & 110 & 34.7 \\
\hline Panjabi \& others & 130 & 41.0 \\
\hline Urdu speaking & 77 & 24.3 \\
\hline \multicolumn{3}{|l|}{ Years of schooling } \\
\hline 10 & 40 & 12.6 \\
\hline 12 & 160 & 50.5 \\
\hline 14 & 82 & 25.9 \\
\hline 16 & 35 & 11.0 \\
\hline \multicolumn{3}{|l|}{ Professional qualifications [no., \%] } \\
\hline MBBS & 25 & 7.9 \\
\hline Registered nurse & 39 & 12.3 \\
\hline Dispenser diploma or others & 225 & 71.0 \\
\hline No professional qualifications & 28 & 8.8 \\
\hline $\begin{array}{l}\text { Hepatitis B complete vaccination } \\
\text { [no., \%] }\end{array}$ & 67 & 21.1 \\
\hline \multicolumn{3}{|c|}{ Practice variables } \\
\hline No. of patients per day [median (range)] & \multicolumn{2}{|c|}{$25(10-40)$} \\
\hline $\begin{array}{l}\text { No. of injections administered per day } \\
\text { [mean }(S D)]\end{array}$ & \multicolumn{2}{|c|}{$65(5.6)$} \\
\hline $\begin{array}{l}\text { No. of injections administered per patient } \\
\text { [median (range)] }\end{array}$ & \multicolumn{2}{|c|}{$2(1-3)$} \\
\hline $\begin{array}{l}\text { At least } 1 \text { sharps injury sustained in last } 12 \\
\text { months [no., \%] }\end{array}$ & 85 & 26.7 \\
\hline \multicolumn{3}{|l|}{$\begin{array}{l}\text { Use of multi-dose vials for injections [no., } \\
\% \text { ] }\end{array}$} \\
\hline Yes & 220 & 69.4 \\
\hline No & 97 & 30.6 \\
\hline \multicolumn{3}{|l|}{$\begin{array}{l}\text { Use of disposable syringe for each } \\
\text { injection }\end{array}$} \\
\hline Yes & 80 & 25.2 \\
\hline No & 237 & 74.8 \\
\hline \multicolumn{3}{|l|}{$\begin{array}{l}\text { Presence of separate container for sharps } \\
\text { disposal [no., \%] }\end{array}$} \\
\hline Yes & 3 & 0.9 \\
\hline No & 314 & 99.1 \\
\hline \multicolumn{3}{|l|}{ Disposal of sharps [no., \%] } \\
\hline Community garbage bin & 250 & 78.9 \\
\hline Sewerage line & 67 & 21.1 \\
\hline \multicolumn{3}{|l|}{ Needle recapping [no., \%] } \\
\hline Yes & 277 & 87.4 \\
\hline No & 40 & 12.6 \\
\hline
\end{tabular}

8.8\% lacked any professional qualifications and only $7.9 \%$ were qualified from a medical school. More than threequarters $(78.9 \%)$ of the practitioners reported that they were not vaccinated against $\mathrm{HBV}$.

\section{Injection practices and prevalence of sharps injury}

A mean of 65 (SD 5.6) injections were being administered per day by each practitioner and three-quarters (74.8\%) of practitioners administered injections with used syringes. A great majority of practitioners $(87.4 \%)$ recapped needles after use and $69.4 \%$ used multidose vials for administering injections. Only 3 practitioners $(<1 \%)$ had separate sharps containers for collecting used syringes and needles and $78.9 \%$ disposed of clinic waste in the community waste collections (Table 1).

A total of 85 practitioners reported at least 1 sharps injury in the previous 12 months, giving an overall prevalence of sharps injury of $26.7 \%$ (95\% CI: $22.2 \%-32.0 \%)$. The prevalence was higher among male practitioners (29.2\%; 95\% CI: $23.8 \%-34.6 \%$ ) than females (10.0\%; 95\% CI: 1.0\%-19\%). Table 2 shows the circumstances around the last sharps injury. More than half of these practitioners had sustained the injury with a used needle (58.8\%) and $47.0 \%$ recalled that the injury occurred while they were recapping the needle after use.

\section{Factors leading to sharps injuries}

Table 3 shows the factors that were significantly associated with sharps injuries. There was a negative relationship between work experience and the rate of sharps injury. The risk of sharps injury was almost 6 times more common among practitioners with $<5$ years' experience as compare to those with $>15$ years' experience (OR $=5.7,95 \%$ CI: $2.5-13.2$ ). As experience increased from $<5$ to $5-10$ years the odds of sharps injury steeply decreased 
to 4-fold ( OR = 3.8, 95\% CI: 1.7-8.9). Similarly, with a further 5 years' increase in experience the odds of sharps injury decreased to 2-fold ( $\mathrm{OR}=1.8,95 \% \mathrm{CI}$ : 0.8-4.2).

The multivariate logistic regression model showed that significant predictors of sharps injuries were: having $<14$ years of schooling $(\mathrm{OR}=6.4,95 \% \mathrm{CI}$ : 3.0-13.9), having $>20$ patients per day (OR $=7.2,95 \%$ CI: $3.0-17.8)$, administering $\geq 30$ injections a day $(\mathrm{OR}=4.7$, $95 \%$ CI: 2.2-10.3) reuse of syringe (OR $=6.2,95 \%$ CI: $2.5-16.5)$ and recapping needle after use $(\mathrm{OR}=3.7,95 \% \mathrm{CI}$ : $1.2-12.7)$.

\section{Discussion}

This study reported that the frequency of sharps injuries among practitioners working in private medical clinics in Landhi town was high. Self-reported injection practices were unsafe and inadequate, for instance reusing syringes, needle recapping, using multi-dose vials, unavailability of sharps disposal containers and disposal of sharps in community waste bins.

This study found that the proportion of practitioners with at least 1 sharps injury in the last 12 months was $26.7 \%$. The literature on the prevalence of sharps injuries among health care practitioners from clinics or primary care facilities in Pakistan and neighbouring countries is very limited. In studies conducted among hospital-based HCW in Karachi a much higher prevalence of sharps injuries was reported: $45 \%$ [6] and 54\% [7]. A similar study conducted in 7 rural health settings in India also reported a higher prevalence (63\%) of at least 1 sharps injury in the last year [8]. Another study carried out among different categories of HCW at a tertiary care hospital in Malaysia found the prevalence of at least 1 sharps injury was $23.5 \%$ : $18.4 \%$ among health care practitioners and $27.9 \%$ among staff nurses [9]. However, multicentre hospital-based cross-sectional studies from the Islamic Republic of Iran and Ethiopia found that the prevalence of at least 1 sharps injury in the last year were similar to our findings: $26.3 \%$ [10] and $29.1 \%$ [11] respectively. In contrast, a study among non-hospital based HCW in the Untied States of America, reported 9\% had had at least 1 sharps injury in the past year [12], which is almost 3 times lower than the rate in our study. Another cross-sectional study conducted among HCW from 2 public hospitals and 136 immunization clinics in the Dominican Republic found that $22.3 \%$ of the HCW had sustained at least 1 sharps injury in the last year [13]. The frequency of sharps injuries was higher in hospitals than immunization clinics where the immunization staff received ongoing training on universal precautions.

Given the current level of percutaneous blood exposure among health care practitioners working in private clinics and the population prevalence of bloodborne pathogens in Pakistan [range 1.4\%-11\% (weighted average $2.4 \%$ ) for HBV and range $0.3 \%-31.9 \%$ (weighted average 3\%) for HCV] [14], the risk of occupational infection with HCV and HBV are high, particularly for those practitioners not vaccinated against hepatitis B. Our results highlight the value of $\mathrm{HBV}$ immunization for all practitioners. Moreover, clinics in rural areas are quite different from hospitals in terms of size, location, facilities, training and professional qualifications of HCW. In most of the facilities the practitioners were not professionally qualified. There is a need for surveillance systems for needlestick/sharps injuries and appropriate facilities for ongoing training of practitioners, refresher courses and provision of personal protective equipment.

In this study, almost three-quarters of the practitioners reported giving injections with used syringes. This proportion is slightly higher than previous findings from primary care facilities in Karachi and other developing countries (range 20\%-60\%) [15,16]. Possible explanations for the higher proportion of syringe reuse in the current study could include being in a slum area where there is no health care regulation, the high proportion of unlicensed or unqualified practitioners ("quacks") in the given

Table 2 Distribution of reasons for injury among practitioners in private medical clinics in Landhi town, Karachi who suffered at least 1 sharps injury in the previous 12 months $(n=85)$

$\begin{array}{lcc}\text { Variable } & \text { No. } & \% \\ \text { Object of sharps injury } & 50 & 58.8 \\ \quad \text { Syringe needle } & 15 & 17.6 \\ \text { Stitching needle } & 10 & 11.8 \\ \text { Surgical blade } & 10 & 11.8 \\ \quad \text { Drip-set needle } & & \\ \text { What led to sharps injury } & 40 & 47.0 \\ \quad \text { Needle recapping } & 15 & 17.6 \\ \text { Patient movement } & 20 & 23.5 \\ \quad \text { Changing of needle } & 10 & 11.8 \\ \quad \text { During discarding in the waste bin } & & \\ \text { Lighting in clinic at time of injury } & 15 & 17.6 \\ \text { Fluorescent lamp } & 20 & 23.5 \\ \quad \text { Regular light bulb } & 30 & 35.3 \\ \quad \text { Rechargeable emergency light } & 20 & 23.5 \\ \quad \text { Candle } & \end{array}$




\begin{tabular}{|c|c|c|c|c|c|c|}
\hline \multirow[t]{3}{*}{ Variable } & \multicolumn{4}{|c|}{ Sharps injury } & \multirow[t]{3}{*}{ OR $(95 \% \mathrm{Cl})$} & \multirow[t]{3}{*}{$P$-value } \\
\hline & \multicolumn{2}{|c|}{ Yes } & \multicolumn{2}{|c|}{ No } & & \\
\hline & No. & $\%$ & No. & $\%$ & & \\
\hline Total & 85 & 26.8 & 232 & 73.2 & & \\
\hline \multicolumn{7}{|c|}{ Years of work experience } \\
\hline$<5$ & 30 & 46.2 & 35 & 53.8 & $5.7(2.5-13.2)$ & \multirow{4}{*}{$<0.001$} \\
\hline $5-10$ & 25 & 36.8 & 43 & 63.2 & $3.8(1.7-8.9)$ & \\
\hline $10-15$ & 18 & 21.2 & 67 & 78.8 & $1.8(0.8-4.2)$ & \\
\hline $15+$ & 13 & 13.0 & 87 & 87.0 & 1 & \\
\hline \multicolumn{7}{|c|}{ Years of schooling } \\
\hline $10-12$ & 75 & 37.5 & 125 & 62.5 & $6.4(3.0-13.9)$ & \multirow[t]{2}{*}{$<0.001$} \\
\hline $14-16$ & 10 & 8.5 & 107 & 91.5 & 1 & \\
\hline \multicolumn{7}{|c|}{ No. of injections administered per day } \\
\hline$<30$ & 10 & 10.0 & 90 & 90.0 & 1 & \multirow[t]{2}{*}{$<0.001$} \\
\hline$\geq 30$ & 75 & 34.6 & 142 & 65.4 & $4.7(2.2-10.3)$ & \\
\hline \multicolumn{7}{|c|}{ No. of patients per day } \\
\hline$\leq 20$ & 7 & 7.1 & 91 & 92.9 & 1 & \multirow[t]{2}{*}{$<0.001$} \\
\hline$>20$ & 78 & 35.6 & 141 & 64.4 & $7.2(3.0-17.8)$ & \\
\hline \multicolumn{7}{|c|}{ Use of disposable syringe for each injection } \\
\hline Yes & 6 & 7.5 & 74 & 92.5 & 1 & \multirow[t]{2}{*}{$<0.001$} \\
\hline No & 79 & 33.3 & 158 & 66.7 & $6.2(2.5-16.5)$ & \\
\hline \multicolumn{7}{|c|}{ Needle recapping after use } \\
\hline Yes & 81 & 29.2 & 196 & 70.8 & $3.7(1.2-12.7)$ & \multirow[t]{2}{*}{0.017} \\
\hline No & 4 & 10.0 & 36 & 90.0 & 1 & \\
\hline
\end{tabular}

$O R=$ odds ratio; $C I=$ confidence interval.

setting as well as unawareness among the general population [17].

This study found that only $1 \%$ of the clinics had puncture-resistant sharps containers for disposing of contaminated sharps. Similar to this finding, Janjua in Muree, Pakistan [18] and, more recently, Chowdhury et al. in Bangladesh [19] also reported that few primary care facilities had sharps disposal containers.

Almost two-thirds of sharps injuries in this study were caused by hollowbore needles, a finding which is consistent with the findings of previous studies among hospital-based HCW in Malaysia [9]. Similarly, the majority of the sharps injury occurred while recapping needles or by manipulation while changing the needle. This is consistent with a previous study at primary care facilities in a rural district of Sindh,
Pakistan [20] and in rural north India [8]. Some of the important considerations regarding involvement of health care practitioners in slum areas in unsafe practice of needle recapping could be unavailability of punctureresistant sharps disposal containers, poor knowledge regarding essential universal precautions [20] as advised by the Centers for Disease Control [21] and reuse of syringes involving manipulation, disassembly and changing of needles [14]. The transmission risk of bloodborne pathogens is relatively greater after sharps injuries caused by used hollow-bore needles [22]. Better awareness is needed about single-use disposable syringes for each patient, perhaps via the media, or training sessions on practising universal precautions for all HCW in private clinics. Improving the availability of sharps disposal containers might be achieved through subsidies to clinics especially in slum areas of Pakistan.

The logistic regression model in this study found that greater work experience, $>14$ years of schooling, having $\leq$ 20 patients per day, administering $<30$ injections per day and not recapping needles or reusing syringes were significantly associated with lower risk of sharps injury. The inverse relationship between work experience and sharps injury is consistent with previous studies conducted at primary care facilities in Pakistan [23,24] and India [8]. The exact reason for the lower risk of sharps injury with increased work experience is unknown; however, the most likely explanation for this association could be attainment of greater skill in carrying out procedures such as injection administration, suturing and cannulation over time. The finding of $<14$ years schooling and higher risk of sharps injury is 
also consistent with a study conducted among HCW in 3 tertiary care hospitals in China [25]. Similarly, the finding of administering more $\geq 30$ injections / day and risk of getting sharps injury is consistent with a multicentre community based cross-sectional survey among different types of health care facilities in the Dominican Republic [13].

The actual rate of sharps injury in the last year among private practitioners in this slum area of Karachi could be higher than reported due to recall bias. Furthermore, the findings may not be generalizable to all settings in the country.

\section{Conclusion}

This study found that practitioners working at private clinics in slum areas of Karachi are at a high risk of bloodborne infections. The prevalence of at least 1 sharps injury in the last year was high and injection practices were unsafe. Health care was provided predominantly by unqualified practitioners who even lacked basic professional qualifications. Less work experience, less than bachelor education, reuse of syringe and practice of needle recapping were significantly associated with sharps injuries. There is an urgent need for commitment by government and medical and nursing associations to enhance awareness about safe injection practices and for health care regulations to avoid transmission risk of bloodborne infections by health care practitioners working in the area studied.

\section{Acknowledgements}

Funding: The study was not funded by any organization and all the expenses were borne by the authors themselves.

Competing interests: None declared.

\section{References}

1. Standard precautions for injection safety. Geneva, World Health Organization Safe Injection Global Network, 2007.

2. Lee R. Occupational transmission of bloodborne diseases to healthcare workers in developing countries: meeting the challenges. Journal of Hospital Infection, 2009, 72:285-291.

3. Health care worker health and safety: preventing needlestick injury and occupational exposure to bloodborne pathogens. Geneva, World Health Organization/International Council of Nurses, 2007.

4. Moghimi M et al. Knowledge, attitude, and practice of Iranian surgeons about blood-borne diseases. Journal of Surgical Research, 2009, 151:80-84.

5. Ali SA et al. Hepatitis B and hepatitis C in Pakistan: prevalence and risk factors. International Journal of Infectious Diseases, 2009, 13:9-19.

6. Zafar A et al. Knowledge, attitude and practices of health care workers regarding needle stick injuries at a tertiary care hospital in Pakistan. Journal of the Pakistan Medical Association, 2008, 58:57.

7. Akhter R et al. Status of hepatitis B vaccination among health care workers and their knowledge about prevention strategies. Journal of Surgery Pakistan, 2006, 11:62-66.

8. Kermode $\mathrm{M}$ et al. Occupational exposure to blood and risk of bloodborne virus infection among health care workers in rural north Indian health care settings. American Journal of Infection Control, 2005, 33:34-41.

9. Rampal L et al. Needle stick and sharp injuries and factors associated with among health care workers in a Malaysian hospital. European Journal of Soil Science, 2010, 13:354-362.

10. Askarian M, Shaghaghian S, McLaws ML. Needlestick injuries among nurses of Fars province, Iran. Annals of Epidemiology, 2007, 17:988-992.

11. Talaat $\mathrm{M}$ et al. Occupational exposure to needlestick injuries and hepatitis B vaccination coverage among health care workers in Egypt. American Journal of Infection Control, 2003, 31:469-474.

12. Gershon RR et al. Non-hospital based registered nurses and the risk of bloodborne pathogen exposure. Industrial Health, 2007, 45:695-704.

13. Moro PL et al. Epidemiology of needlesticks and other sharps injuries and injection safety practices in the Dominican Re- public. American Journal of Infection Control, 2007, 35:552559.

14. Ali SA et al. Hepatitis B and hepatitis C in Pakistan: prevalence and risk factors. International Journal of Infectious Diseases, 2009, 13:9-19.

15. Janjua NZ, Akhtar S, Hutin YJ. Injection use in two districts of Pakistan: implications for disease prevention. International Journal for Quality in Health Care, 2005, 17:401-408.

16. Lee R. Occupational transmission of bloodborne diseases to healthcare workers in developing countries: meeting the challenges. Journal of Hospital Infection, 2009, 72:285-291.

17. Ahmed K. Pakistan: a cirrhotic state? Lancet, 2004, 364:18431844.

18. Janjua NZ. Injection practices and sharp waste disposal by general practitioners of Murree, Pakistan. Journal of the Pakistan Medical Association, 2003, 53:107-111.

19. Chowdhury AK et al. A comprehensive situation assessment of injection practices in primary health care hospitals in Bangladesh. BMC Public Health, 2011, 11:779.

20. Janjua NZ et al. Poor knowledge-predictor of nonadherence to universal precautions for blood borne pathogens at first level care facilities in Pakistan. BMC Infectious Diseases, 2007, 7:81.

21. Universal precautions for prevention of transmission of human immunodeficiency virus, hepatitis B virus, and other bloodborne pathogens in health-care settings. Morbidity and Mortality Weekly Report, 1988, 37(24):377-388.

22. Bowden FJ. Needle-stick injuries in primary care. Australian Prescriber, 2001, 24:98-100.

23. Janjua NZ, Khan MI, Mahmood B. Sharp injuries and their determinants among health care workers at first-level care facilities in Sindh Province, Pakistan. Tropical Medicine and International Health, 2010, 15:1244-1251.

24. Yousafzai MT, Siddiqui AR, Janjua NZ. Health belief model to predict sharp injuries among health care workers at first level care facilities in rural Pakistan. American Journal of Industrial Medicine, 2013, 56(4):479-487.

25. Tang PF et al. Incidence and risk factors for sharp injury among health care workers in three hospitals in Kunming, China. Journal of Nursing Science, 2009, 27:42-48. 